\title{
ГЕШТАЛЬТНИЙ РІЗНОВИД АСОЩІАТИВНО-МЕТАФОРИЧНОЇ МОТИВАЦІї НАУКОВО-ТЕХНІЧНИХ АНАЛІТИЧНИХ ТЕРМІНІВ
}

\author{
ЛІЛІЯ ГАРАЩЕНКО \\ Полтавський національний технічний університет імені Юрія Кондратюка, \\ Полтава - Україна \\ liliya.garashenko@gmail.com; ORCID: 0000-0002-0314-0792 \\ GESTALT A ODMIANA ASOCJACYJNO-METAFORYCZNEJ MOTYWACJI \\ NAUKOWO-TECHNICZNYCH TERMINÓW ANALITYCZNYCH \\ LILIA HARASZCZENKO \\ Połtawski Narodowy Uniwersytet Techniczny imienia Jurija Kondratiuka, \\ Połtawa - Ukraina
}

STRESZCZENIE. Artykuł poświęcono specyfice motywacji naukowo-technicznych terminów analitycznych pod kątem mechanizmów ich tworzenia. Autorka zwraca szczególną uwagę na Gestalt — odmianę asocjacyjno-metaforycznej motywacji terminów, charakteryzującą się wyborem motywatorów oznaczających obiekty naukowo-techniczne na podstawie podobieństwa obrazów wzrokowych (Gestalt). Omówione zostały podstawowe obszary dostarczające własne środki znakowe do tworzenia terminologii naukowo-technicznej.

Słowa kluczowe: terminy analityczne, terminologia naukowo-techniczna, motywacja asocjacyjno-metaforyczna, motywator, Gestalt, obszar dawcy.

\section{GESTALT TYPE OF SCIENTIFIC-TECHNICAL ANALYTIC TERMS' ASSOCIATIVE-METAPHORICAL MOTIVATION}

\author{
LILIIA HARASHCHENKO \\ Poltava Yuri Kondratyuk National Technical University, Poltava — Ukraine
}

ABSTRACT. The article focuses on the specificity of the scientific-technical analytic terms due to the cognitive mechanisms of their creation. It has been ascertained the gestalt type of terminological units' associative-metaphorical motivation makes the motivators' selection possibility, denoting the scientific-technical objects after the visual images (gestalts). The fact the dominant donor zones supply its sign resources to the scientific-technical terminology has been proved in succession.

Key words: analytic terms, scientific-technical terminology, associative-metaphorical motivation, motivator, gestalt, donor zone.

$\mathrm{H}$ аукові терміни справедливо вважають інструментами пізнавальної діяльності людства. Саме тому дослідники так прискіпливо ставляться до термінів, визначення їхніх дефініцій, однозначності висловлювань. У науково-технічних текстах функціюють особливі одиниці мови - термінологічні словосполучення (аналітичні терміни), що номінують різноманітні поняття субстанції та іiі різновиди, явища, дії, процеси тощо. За спостереженнями науковців, терміносполуки становлять понад 70 \% загальної кількості термінологічних одиниць у різних терміносистемах (праці М. Годованої, Б. Михай- 
лишина, О. Іващишин, О. Чумак, Л. Малевич, О. Чуєшкової, Д. Шапран, Л. Козак й ін.).

На сьогодні актуальним і принциповим для розв'язання низки термінологічних проблем $є$ вивчення питань, пов'язаних із визначенням лінгвістичного статусу таких одиниць, а також аналіз категорійних особливостей аналітичних термінів. Більшість науковців зосереджує увагу на граматичній структурі аналітичних номінацій, репрезентуючи повний спектр тих моделей, за якими побудовано термінологічні конструкції. Значно менше уваги приділено аналізу семантичної організації цих лексичних одиниць, зокрема під когнітивноономасіологічним кутом зору, з'ясуванню когнітивної бази мотивації терміносполук.

Мета цієї статті - розглянути гештальтний різновид асоціативно-метафоричної мотивації науково-технічних аналітичних термінів. Об'єктом пропонованої розвідки $€$ аналітичні номінації науково-технічної термінології, а предметом - ономасіологічні ознаки аналітичних термінів і когнітивні механізми їхнього творення.

Традиційно словосполучення визначають як граматичне та змістове поєднання двох або більше повнозначних слів (чи словоформ), що зі змістового боку є складним найменуванням явищ дійсності, а з формально-синтаксичного - сполученням повнозначних слів за допомогою підрядного або сурядного зв'язку ${ }^{1}$. У лінгвістиці існує кілька поглядів на статус аналітизму як такого, що зумовлене його існуванням на рівні граматики (граматичної форми) й на рівні лексики (поєднання повнозначних лексичних одиниць). Здебільшого аналітизм розуміють як розчленованість лексичного та граматичного значень. Як зауважує А. Загнітко, „постання і розвиток аналітичних форм, конструкцій пов’язані 3 процесом граматизації словосполучень. Остання зумовлена послабленням або втратою лексичного значення одного 3 компонентів словосполучення"2.

Аналітичні терміни відображають результати пізнавальної діяльності людини, віддзеркалюють роботу людської когніції, процесів категоризації та концептуалізації, що є двома формами пізнання світу у вигляді класифікаційної діяльності розуму людини. Когнітивна природа інформації, яку передають аналітичні терміни, найрелевантніша для здійснення комунікації.

3 метою 3'ясування когнітивної бази мотивації науково-технічних аналітичних термінів було використано розроблену О. Селівановою методику когнітивно-ономасіологічного аналізу, що грунтується на принципі інтегративної двовекторності дослідження (від ономасіологічної структури аналітичних термінів до структури знань про позначене й навпаки) та на психолінгвістичній моделі породження (продукування) номінативних одиниць. Мотивацію з огляду на психолінгвістичну модель породження найменування витлумачено як наскрізну лінгвопсихоментальну операцію формування ономасіологічної структури, що здійснюється шляхом вибору мотиватора (-ів) з мотиваційної бази структури знань про позначене в складній системі зв'язків різних пізнавальних функцій етносвідомості ${ }^{3}$. Когнітивно-ономасіологічний аналіз науковотехнічних аналітичних термінів дав можливість встановити мотиваційну типологію спеціальних найменувань. Залежно від статусу обраних мотиваторів ана-

1 І. Р. Вихов ванець, Граматика украйнської мови. Синтаксис, Київ 1993, с. 9.

2 А. П. Загнітко, Теорія сучасного синтаксису, вид. 3-тє, виправл. і доп., Донецьк 2008, c. 227.

3 О. О. С елів ванов ва, Лінгвістична енциклопедія, Полтава 2010, с. 482. 
літичних термінів у структурі знань про позначене виокремлено три типи мотивації: пропозиційно-диктумну, асоціативно-метафоричну й змішану.

Внутрішня програма термінологічної одиниці може мати не лише пропозиційний, а й асоціативно-метафоричний характер, оскільки мотиваційна база не обмежена лише пропозиціями, а є складною структурою зв'язків і кореляцій функцій свідомості та іiі різних за статусом фрагментів. Асоціативнометафорична мотивація, на відміну від пропозиційно-диктумної, грунтується на використанні в ролі мотиваторів знаків різних предметних сфер і за загальним механізмом найменування є метафоричною, оскільки в процесі найменування застосовується фрагмент неістинних знань про позначене.

Асоціативно-метафорична мотивація характеризується вибором мотиватора похідного найменування „на основі асоціювання 3 диктумною частиною когнітивної моделі інших концептів, що формує термінальні компоненти в такій моделі" ". Асоціативно-термінальна частина ментально-психонетичного комплексу пов'язує знаки різних сфер знань за аналогією. Аналогізація концептуальних сфер може мати характер синестезії або симіляції. Синестезія як явище міжсенсорної семантичної асоціації в мові базується на перенесенні знака з однієї до іншої сфери відчуттів. Основні напрями їі розвитку - сфери зору та слуху. Асиміляція виявляється в подібності усвідомлюваних мовцем ситуацій, компоненти яких і формують буквальний та фігуральний зміст.

Асоціативно-метафорична мотивація грунтується на метафоричному асоціюванні. За допомогою асоціацій як основного двигуна механізмів мислення, як слушно зауважує В. Телія, створюються нові поняття й значення номінативних одиниць, оскільки вони пов'язують уявлення про позамовні сутності з тими їхніми властивостями, що випливають у свідомості в тому чи тому новому ракурсі відображення 5 . Г. Скляревська зазначає, що „природжене почуття аналогії примушує людину відшукати схожість між найвіддаленішими сутностями"б.

У процесі метафоризації науково-технічних термінів важливу роль відіграє донорська зона, властивості якої проектуються на реципієнтну, унаслідок “висвітлюються" одні аспекти й “затемнюються” інші. Донорською зоною $\epsilon$ концептуалізовані сутності об’ єктів реальної дійсності, що зафіксовані в значеннях номінативних одиниць. 3-поміж асоціативно мотивованих компонентів аналітичних термінів виділяємо передусім терміни, значення яких спирається на метафоричне сприймання мотиватора як знака іншої концептуальної сфери.

У корпусі асоціативно мотивованих компонентів термінологічних конструкцій залежно від способу взаємодії донорської та реципієнтної зон було виокремлено три різновиди асоціативно-метафоричної мотивації: структурнометафоричний, дифузно-метафоричний і гештальтний.

Гештальтний (образний) різновид асоціативно-метафоричної мотивації застосовує у функції мотиваторів знаки інших концептів за подібністю зорових, слухових, одоративних, тактильних, смакових гештальтів ${ }^{7}$. При цьому поєднуються різні сутності, що формують новий гештальт, нові відношення з редукованих прототипів, утворюючи на його основі певний гносеологічний образ і синтезуючи в ньому ознаки гетерогенних сутностей.

${ }^{4}$ Е. А. С ел и ван ов а, Когнитивная ономасиология, Киев 2000, с. 172.

5 В. Н. Телия, Коннотативный аспект семантики номинативных единии, отв. ред. А. А. У фим це в а, Москва 1986, с. 94.

6 Г. Н. Скляре в ская, Языковая метафора в словаре. Опыт системного описания, [в:] „Вопросы языкознания”, 1987, № 2, с. 58.

${ }^{7}$ Е. А. Сели ван ов а, указ. источ., с. 174. 
Термін “гештальт" був уведений одним 3 попередників гештальтпсихології X. Еренфельсом наприкінці XIX ст. Представники гештальтпсихології (М. Вертгеймер, В. Келер, К. Коффка) започаткували новий підхід до мислення, розглядаючи його як акт переструктурування ситуацій. На думку дослідників, первинними й визначальними елементами кожного психічного процесу $є$ цілісні утворення-конфігурації, форми, або гештальти, які неможливо побудувати 3 якихось елементів. У когнітивній лінгвістиці гештальт потрактовують як концептуальну структуру, цілісний образ, що поєднує чуттєві та раціональні компоненти в їхній цілісності, як результат нерозчленованого сприйняття ситуації, вищий рівень абстракції: недискретне, неструктуроване знання 8 .

Гештальтний різновид асоціативно-метафоричної мотивації науковотехнічних аналітичних термінів передбачає вибір мотиватора зі знаків іншої концептуальної сфери, що зумовлює зв'язок із позначуваним на основі образу, за яким проводиться аналогізація. Механізм такої метафоризації грунтується зазвичай на уподібненні зорових образів до форми чи зовнішнього вигляду предмета, деталі, приладу тощо, які використовуються в науково-технічній галузі. Гештальтна аналогізація доповнюється семантичною та смисловою, оскільки гештальтний знак має певний зміст і значення.

У процесі гештальтування науково-технічних термінів основну базу метафоричної проекції становлять антропоморфізми, зооморфізми, артефакти й природоморфізми. Метафори таких типів здебільшого грунтуються на зіставленні об'єктів, що застосовуються в галузі науки й техніки, з уже відомим зоровим гештальтом.

У науково-технічній термінології найпродуктивнішою $є$ модель метафоричного перенесення „АРТЕФАКТИ - ПРИСТОСУВАННЯ”. Метафори цього типу моделюють світ за подібністю до артефактів (предметів, створених людиною). Аналіз ядерних компонентів термінологічних конструкцій уможливив виокремлення п'яти груп артефактів, що стали метафоричними мотиваторами термінів: 1) назви предметів домашнього побуту. В ономасіологічній структурі аналітичного терміна колиска підойми (заг. - невеличке ліжечко для спання і колисання дитини'9; терм. - 'почіпний поміст 3 бортами для піднімання інструмента, матеріалів ${ }^{10}$ ) ядерний компонент утворився на грунті цілісної зорової подібності помосту до форми реалії із цієї донорської зони; 2) найменування одягу чи його частин, головних уборів. Аналітичний термін затискна муфта а (заг. - рід жіночого туалету з хутра або тканини на ваті для зігрівання рук; терм. - 'деталь у вигляді невисокого циліндра для поздовжнього з'єднування валів, труб, зубчастих коліс та інших циліндричних або призматичних частин машин чи споруд'11) мотивований подібністю форми деталі до предмета жіночого гардероба; 3) назви прикрас й аксесуарів. Ядерні компоненти аналітичних термінів цієї групи розвивають вторинні значення на основі актуалізації зорових образів. Так, стрижневий компонент терміна шарнірна серга (заг. - прикраса у вигляді кільця, підвіска та ін., дужка якої просмикується в мочку вуха (у деяких наро-

${ }^{8}$ Н. Н. Болдырев, Когнитивная семантика: Курс лекций по английской филологии, Тамбов 2001, с. 38.

9 Великий тлумачний словник сучасної украӥнської мови, уклад. і гол. ред. В. Т. Бусел, Київ; Ірпінь 2005, с. 554.

${ }_{10}$ Російсько-украӥнський словник з інженерних технологій, уклад.: М. Ган іт кев ич, Б. Кі н аш, Термінографічна серія СловоСвіт, № 9, Львів 2004, CD.

${ }_{11}$ Великий тлумачний словник сучасної украӥнської мови..., с. 697. 
дів - у носову перетинку)'; терм. — 'пристрій у вигляді кільця або напівкільця для підвішування або з'єднання різних предметів'12) отримав свою назву внаслідок подібності форми пристрою, що нагадує жіночу прикрасу; 4) назви споруд, їхніх частин. Аналітичний термін підвісний поміст (заг. - 'підвищення, площадка, збита з дощок'; терм. - 'рівна підвісна площадка, зроблена 3 твердого матеріалу, з якої здійснюється кріплення ствола шахти'13) грунтується на гештальтному уподібненні спеціального пристосування до підвищення; 5) назви продуктів харчування. Підгрунтям метафоризації таких назв в ономасіологічній структурі термінів є подібність зорових або смакових гештальтів. Напр., у номінації артилерійське сало (заг. жирове відкладення у тілі живого організму, жир'; терм. - 'різновид мастила, яким змащують металеві частини крупнокаліберної зброї (гармат) під час довгострокового зберігання (консервації) ${ }^{14}$ ) репрезентовано уподібнення матеріалу до розтопленого тваринного жиру.

Основою аналогізації може бути уподібнення внаслідок отриманих суб'єктом смакових відчуттів про певний об'єкт під час безпосереднього контакту з ним. Напр., в ономасіологічній структурі терміна трунтовий розciл (спец. - 'водний розчин солей, що застосовується в техніці' ${ }^{15}$ ) знак розсіл указує на подібність водного розчину до солоної рідини, спеціально приготовленої для засолювання овочів, риби тощо. Але кількість компонентів науково-технічних аналітичних термінів, мотивованих гештальтно за смаковою ознакою, незначна.

Отже, застосування мотиваторів донорської зони АРТЕФАКТИ на позначення науково-технічних понять грунтується на подібності форми й ознаки зовнішнього вигляду об' єкта номінації до предметів навколишнього світу. За нашими спостереженнями, відзначається певна кореляція між пунктом відправлення й пунктом призначення. Мотиватори донорської зони АРТЕФАКТИ використовуються переважно для позначення різноманітних пристосувань, пристроїв і деталей механізмів.

Активною в науково-технічній термінології $є$ й донорська зона ЛЮДИНА, що пояснюється принципом антропоцентризму, коли людина сприймає й уподібнює довкілля через порівняння із собою. Ця донорська зона неоднорідна, і способи перенесення найменувань із цієї концептосфери різноманітні. Вона репрезентована мовними знаками, що характеризують людину як носія певних властивостей і вживаються на позначення інших предметних сфер, зокрема науково-технічних понять. За спостереженнями М. Міллера, саме антропоморфізми виступають базисною метафорою, необхідною для розвитку нашої мови й свідомості, пізнання й осмислення дійсності ${ }^{16}$. Здавна людина бачила в різноманітних проявах природи аналог власного життя й несвідомо переносила на предмети і явища довкілля свої відчуття, намагаючись пізнати не стільки зовнішній світ, скільки внутрішній ${ }^{17}$. Пізнання навколишнього світу відбувається в процесах діяльності - власне життєдіяльності та когнітивної діяльності. Освоюючи світ, людина здатна ,порівнювати все нове для неї (у тому числі

12 Там само, с. 1308.

13 Там само, с. 1042.

14 Там само, с. 1285.

15 Там само, с. 1263.

16 Дж. Миллер, Образы и модели, уподобления и метафоры, [в:] Теория метафоры, сб., под общ. ред. Н. Д. А рутюн ов ой, М. А. Жур ин ской, Москва 1990, с. 280.

${ }_{17}$ К. Г. Юн г, Архетип и символ, сост. и вступ. ст. А. М. Рутке в ич а, Москва 1991, с. 304. 
й реально несумісне) за їі образом і подобою або ж за об'єктами, що сприймаються просторово, з якими людина має справу в практичному досвіді" 18.

Метафоричний механізм гештальтування характеризується зазвичай уподібненням зорових образів до форми механізмів, приладів, пристосувань, деталей тощо. Зокрема, партитиви з донорської зони ЛЮДИНА передають різноманітні конфігурації форми об’ єктів, що застосовуються в науково-технічній галузі: а) клиноподібна — борідка ударника (заг. — 'зменшене до борода'; терм. — 'шпеник, виступ у ключі' ${ }^{19}$ ), подвійний язичок (заг. - 'зменшено-пестливе до язик'; терм. - 'рухома, прикріплена одним кінцем пластинка в різних предметах або механізмах'20); б) заокруглена - буксирувальне вушко (заг. ‘зменшено-пестливе до вухо'; терм. - 'отвір у пристрої, механізмі, куди щонебудь вставляється' ${ }^{21}$ ) тощо.

Аналогізація донорської зони ЛЮДИНА й реципієнтної зони ПРИСТОСУВАННЯ може здійснюватися на грунті схожості місця розташування предметів позамовної дійсності, напр.: голова палі (заг. - ччастина тіла людини або тварини, у черепі якої міститься головний мозок; // основне, головне в чомунебудь'22); нога опори (заг. - 'одна 3 двох нижніх кінцівок людини'; терм. 'опора меблів, споруд, механізмів і т. ін. $\left.{ }^{23}\right)$. Партитиви голова, нога є асоціатами локатива цих концептів.

Явище переходу назв частин та органів тіла людини в науково-технічні терміни є закономірністю, оскільки пізнання світу людиною, ііі когнітивний досвід починаються 3 пізнання найближчої дійсності, якою є власне тіло — форма існування особистості. За нашими спостереженнями, основною сферою метафоричного застосування назв частин тіла людини є термінація механізмів, пристроїв, приладів, деталей обладнання, а також їхніх частин.

У науковій літературі метафори, донорськими зонами яких є тварини, називають зооморфними. Зооморфний тип охоплюють аналітичні терміни, компоненти яких утворені на основі метафоризації за подібністю до зовнішнього вигляду тварин, птахів чи інших істот або частин їхнього тіла. Аналогізація властивостей донорської зони ТВАРИНА й реципієнтної зони ПРИСТРОЇ відбувається на грунті схожості механізмів, пристосувань, їхніх частин із частинами тіла тварин. Напр., найменування трелювальна лебідка (машина, пристрій для підіймання й переміщення вантажів ${ }^{24}$ ) мотивоване подібністю довгого важеля лебідки до шиї лебедя. Стрижневий компонент аналітичного терміна перо керма (заг. - рогове нашкірне утворення з порожнистим стрижнем і легкими пухнастими відростками з обох боків, яке вкриває більшу частину тіла птахів'; терм. - 'лопать деяких інструментів, пристосувань і т. ін. ${ }^{25}$ ) спирається на зовнішнє уподібнення плаского кінця частини пристрою до пера птаха.

Гештальтування може здійснюватись і в межах донорської зони НАТУРФАКТ. У сфері натурфактів деякі дослідники виокремлюють назви ділянок земної поверхні й назви, що позначають світлові та звукові явища, запахи, вогонь,

18 Е. Ю. Махницкая, Метафора в профессиональном языке экономистов, [в:] Актуальные проблемы филологии и методики преподавания, межвуз. сб. науч. статей, Ростов-на-Дону 2001, c. 68 .

19 Великий тлумачний словник сучасної украйнської мови..., с. 93.

20 Там само, с. 1646.

21 Там само, с. 212.

22 Там само, c. 250.

23 Там само, с. 790.

24 Там само, с. 608.

25 Там само, с. 938. 
дим ${ }^{26}$. До натурфактів-мотиваторів науково-технічних термінів належать складники таких сфер: природні об’єкти, атмосферні явища, рослини. Метафоричні проекції цієї донорської сфери моделюють дійсність за аналогією до елементів певної місцевості на основі актуалізації зорових образів, пов'язаних з особливостями сприйняття предметів, що застосовуються в науково-технічній галузі. Напр., у номінації западина вала (заг. - заглиблене місце на чому-небудь; яма, ямка ${ }^{27}$ ) перенесення 3 донорської до реципієнтної зони здійснюється на грунті зовнішньої схожості. Аналогічний мотиваційний механізм застосовано в термінологічних найменуваннях мастильний рівчак, гвинтова канавка, ланцюгова зірочка.

Метафори, що моделюють дійсність за аналогією до рослини, іiі частин чи плодів, називають фітоморфними. Так, ядерний компонент аналітичного терміна ливарна шишка (заг. - 'суцвіття хвойних та деяких інших рослин, перев. круглої чи овальної форми, вкрите лусочками'; терм. - 'те саме, що стрижень'; // 'потовщення круглої чи овальної форми на кінці, верхівці якогось предмета ${ }^{28}$ ) відображає подібність зорових відчуттів, що опосередковують гештальтну природу мотивації концептосфери НАТУРФАКТ. Найменування імnлічитне дерево виникло внаслідок метафоричного перенесення знака дерево, опосередкованого загальною схожістю системи об'єктів до будови рослини; буровий стовбур - метафорично мотивується уподібненням зовнішнього вигляду системи підземних споруд до частини рослини.

Отже, у корпусі досліджуваних асоціативно мотивованих ядерних компонентів науково-технічних аналітичних термінів гештальтний різновид цього типу мотивації $є$ найпоширенішим. Як основні донорські зони, що постачають свої знакові ресурси для реципієнтних ПРИСТОСУВАННЯ, ПРИЛАДИ, ДЕТАЛІ, ІНСТРУМЕНТИ, використано концептосфери ЛЮДИНА, ТВАРИНА, АРТЕФАКТИ Й НАТУРФАКТИ.

\section{Список використаної літератури}

Бацевич Ф. С., Космеда Т. А., Очерки по функииональной лексикологии, Львов 1997.

Болдырев Н. Н., Когнитивная семантика: Курс лекиий по английской филологии, Тамбов 2001.

Великий тлумачний словник сучасної украӥнської мови, уклад. і гол. ред. В. Т. Бусел, Київ; Ірпінь 2005.

Вихованець І. Р., Граматика української мови. Синтаксис, Київ 1993.

Загнітко А. П., Теорія сучасного синтаксису, Донецьк 2008.

Махницкая Е. Ю., Метафора в профессиональном языке экономистов, [в:] Актуальные проблемы филологии и методики преподавания, межвуз. сб. науч. статей, Ростовна-Дону 2001.

Миллер Дж., Образы и модели, уподобления и метафоры, [в:] Теория метафоры, сб. под общ. ред. Н. Д. Арутюновой, М. А. Журинской, Москва 1990.

Російсько-украӥнський словник з інженерних технологій, уклад.: М. Ганіткевич, Б. Кінаш, № 9, Львів 2004.

Селиванова Е. А., Когнитивная ономасиология, Киев 2000.

Селіванова О. О., Лінгвістична енциклопедія, Полтава 2010.

Скляревская Г. Н., Языковая метафора в словаре. Опыт системного описания, [в:] „Вопросы языкознания", 1987, № 2.

\footnotetext{
${ }^{26}$ Ф. С. Б а ц в в и ч, Т. А. Ко с м е да, Очерки по функииональной лексикологии, Львов 1997, с. 148.

${ }^{27}$ Великий тлумачний словник сучасної украӥнської мови..., с. 410.

28 Там само, с. 1622.
} 
Телия В. Н., Коннотативный аспект семантики номинативных единиц, отв. ред. А. А. Уфимцева, Москва 1986.

Юнг К. Г., Архетип и символ, сост. и вступ. ст. А. М. Руткевича, Москва 1991.

\section{Spysok vykorystanoi literatury [References]}

Bacevich F. S., Kosmeda T. A., Ocherki po funkcional'noj leksikologii [Sketches on Functional Linguistics], Lvov 1997.

Boldyrev N. N., Kognitivnaya semantika: Kurs lekcij po anglijskoj filologii [Cognitive Semantics: Lecture Course on English Philology], Tambov 2001.

Velykyi tlumachnyi slovnyk suchasnoi ukrainskoi movy [Big Explanatory Dictionary of Modern Ukrainian], uklad. i hol. red. V. T. Busel, Kyiv-Irpin 2005.

Vykhovanets I. R., Hramatyka ukrainskoi movy. Syntaksys [Ukrainian Language Grammar. Syntax], Kyiv 1993.

Zahnitko A. P., Teoriia suchasnoho syntaksysu [Theory of Modern Syntax], Donetsk 2008.

Mahniczkaya E. Yu., Metafora v professionalnom yazyke ekonomistov [Metaphor in Professional Language of Economists], [v:] Aktualnye problemy filologii i metodiki prepodavaniya, mezhvuz. sb. nauch. statej, Rostov-na-Donu 2001.

Miller Dzh., Obrazy i modeli, upodobleniya i metafory [Images and Models, Metaphors], [v:] Teoriya metafory, sb. pod obsh. red. N. D. Arutyunovoj, M. A. Zhurinskoj, Moskva 1990.

Rosiisko-ukrainskyi slovnyk z inzhenernykh tekhnolohii [Russian-Ukrainian Dictionary of Engineering Technology], uklad.: M. Hanitkevych, B. Kinash, № 9, Lviv 2004.

Selivanova E. A., Kognitivnaya onomasiologiya [Cognitive Onomasiology], Kiev 2000.

Selivanova O. O., Linhvistychna entsyklopediia [Linguistic Encyclopedia], Poltava 2010.

Sklyarevskaya G. N., Yazykovaya metafora v slovare. Opyt sistemnogo opisaniya [Language Metaphor in Dictionary. Experience of Systematic Description], [v:] ,Voprosy yazykoznaniya", 1987, № 2.

Teliya V. N., Konnotativnyj aspekt semantiki nominativnyh edinic [Connotative Aspects of Nominative Units Semantics], otv. red. A. A. Ufimceva, Moskva 1986.

Yung K. G., Arhetip i simvol [Architype and Symbol], sost. i vstup. st. A. M. Rutkevicha, Moskva 1991. 